\title{
Van jaarrekeningcontrole naar assurance services
}

\section{Luc van Zutphen}

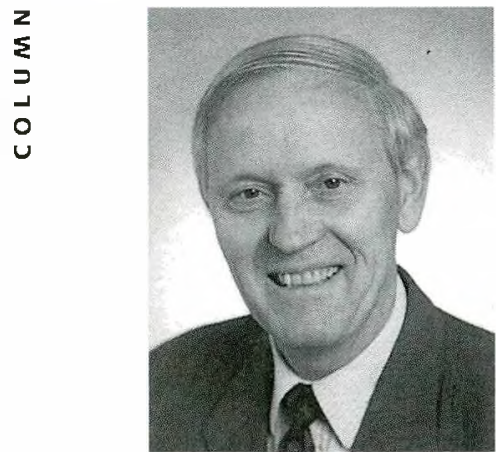

In accountantsland gonzen al enkele jaren nieuwe termen door de lucht.

Auditing en control verdringen oude en vertrouwde woorden als jaarrekeningcontrole en interne controle. De laatste tijd w'ordt ook steeds meer gesproken en geschreven over assurance services, door sommigen al vertaald met zekerheidsdiensten. Dit overigens mooie Nederlandse woord zal wel niet beklijven in onze moderne internationaal georiënteerde maatschappij. Net zo min als magneetbandeenheid en rekenautomaat het ooit hebben gewonnen van tape unit en computer.

Vooral assurance services - als nieuw en aan'ullend werkdomein roor accountants - staan de laatste tijd zeer in de belangstelling. Assurance services, op te vatten als een moderne respons van het accountantsheroep op nieuwe maatschappelijke verwachtingen en behoeften van de gebruikers van accountantsdiensten.

In de baanbrekende studie 'Auditing into the Tw'enty-First Century' van het Schotse Instituut stijgen deze 'public expectations' ver uit boven het traditionele jaarverslag en de daarin opgenomen uitkomsten van de huidige wettelijk verplichte jaarrekeningcontrole. Naleving van

Prof. L.C. van Zutphen RA is emeritus hoogleraar Accountantscontrole aan de Vrije Universiteit te Amsterdam. Daarnaast is hij voorzitter van het Examenbureau Registeraccountants en lid van de Orde van Organisatiedeskundigen en -Adviseurs. wetten en regels, de kwaliteit van het internal control systeem inclusief IT control, de uitkomsten van milieubeheersing. de continuiteit van de onderneming en dergelijke behoren volgens dit Schotse rapport eveneens onderwerpen van verantwoording en controle te zijn. En om de verbreding van de controlebehoeften verder te accentueren wordt door de auteurs de voorkeur gegeven aan de nieuwe beroepsaanduiding assessor in plaats van accountant.

Assurance services, wat moet onder een dergelijke dienstverlening worden verstaan. welke (nieuwe) marktvraag bestaat er voor dit type diensten en kunnen accountantskantoren en -diensten daarin voorzien?

Door vele beroepsgenoten wordt op deze en andere vragen met de nodige aarzeling en reserve geantwoord. Het is dus tijd voor een nadere verkenning bij onze buitenlandse collega's, met name in de Verenigde Staten en Canada.

Ongeveer twee jaar geleden startten in beide landen studies naar de noodzaak en de mogelijkheden tot expansie van de attestfunctie, zo nauw' gekoppeld aan de behoefte tot certificering van de jaarrekening. Het Canadian Institute of Chartered Accountants organiseerde een Task Force on Assurance Services en vrijwel tezelfdertijd een zogenaamde Vision Task Force, die tot taak had de toekomstige rollen van de CA te verkennen en daarover te adviseren.

Als een van de belangrijkste conclusies van de Vision Task Force werd genoteerd dat:

'CA's have not kept pace with the expanding range of information needed by the financial 
markets. Although traditionnally the profession has focused on and achieved leadership by developping standards for accounting and auditing activities related to annual financial accounts, these efforts are not seen to be responding to evolving public expectations, advances in information and communication technology, and globalization.'

Financieel-economisch werden de gevolgen daarvan zichtbaar gemaakt door het Amerikaanse Special Committee on Assurance Services. Voor de zestig grootste accountantskantoren in de VS w'erd vastgesteld dat de omzet in de sector accountancy - na correctie voor inflatie - de afgelopen zeven jaar niet was gegroeid. In 1995 was er zelfs sprake van een daling. Uiteraard wordt dit ook - en wellicht in belangrijke mate veroorzaakt door verschijnselen als toegenomen concurrentie, efficiencyvergroting en toepassing van informatietechnologie.

Ook de onderzoekers in de VS concluderen dat $C P A$ 's nieuwe assurance services moeten ontwikkelen; services die een toegevoegde waarde inhouden voor managers en mogelijkheden tot een nieuwe groei-impuls voor accountantskantoren in dit belangrijke marktsegment.

Een belangrijke strofe uit het interim-rapport van het Special Committee Iuidt:

'Much of the audit service, at least for public entities, is regulatorily-driven, not marketdriven. The demand for the service as it's currently constituted is artificially created through government statute. Licensing requirements (appropriately) limit the practice to CPA's. Any change in either of these factors would result in tremendous discontinuities for the profession.'

Als w'e beide uitspraken op hun relevantie voor de Nederlandse en Europese markt beoordelen kan de conclusie geen andere zijn dan dat de geformuleerde trends, factoren en risico's ook in onze omgeving kunnen worden waargenomen c.q. van toepassing zijn.

Zowel bij de Canadese als de Amerikaanse beroepsorganisatie bestaat de overtuiging dat zij een gidsfunctie voor hun leden hebben te vervullen.

In het interimrapport van het AICPA Special Committee wordt een poging ondernomen de assurance services als duidelijk te onderscheiden segment van zakelijke dienstverlening in beeld te brengen. Leidend daarbij is de gekozen definitie van assurance services, te weten:

\section{'Independent professional services that improve the quality of information, or its context, for decision makers'}

Assurance services op deze elastische manier omschreven beperken zich niet tot de traditionele accountantswerkzaamheden; integendeel het beoogde vakgebied is veel breder. De eis van een eigen verantwoording door de cliënt of enige andere voorstelling van zaken komt in de definitie niet voor. Bovendien kunnen ook andere aspecten dan betrouwbaarheid en continuiteit van informatie onderwerp van assurance zijn.

Maar onze Amerikaanse collega's graven nog een spade dieper en proberen in matrix-vorm de huidige en toekomstige mogelijkheden voor assurance services door accountants in beeld te brengen. Uitgangspunten daarbij waren de (toekomstige) cliënten van accountants en hun informatiebehoeften en de daarmee samenhangende assurance.

Cliënten nader gedefinieerd als personen die informatie gebruiken voor beslissingsdoeleinden. Aldus ontstaat het volgende beeld:

\section{NEW ASSURANCE OPPORTUNITIES}

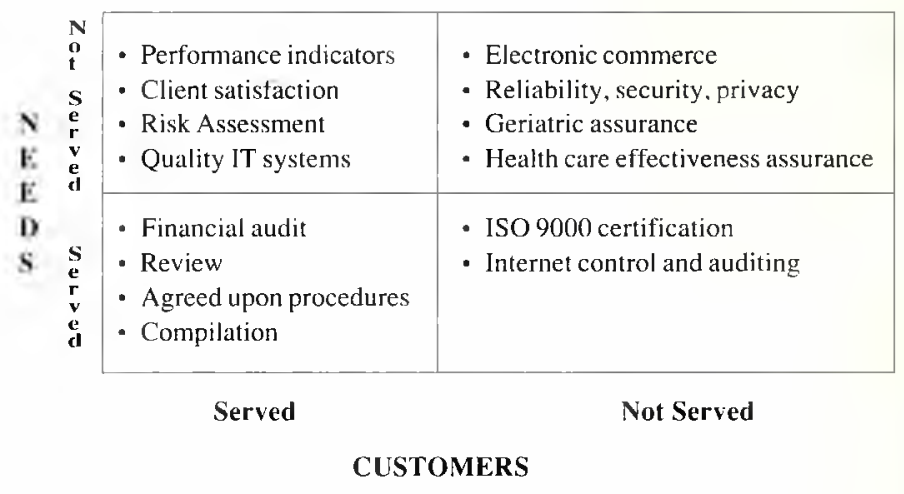

(Bron: AICPA 1996)

In het kwadrant linksonder zijn de huidige accountantsdiensten weergegeven, waarbij te denken valt aan controleopdrachten, beoordelingsopdrachten, samenstellingsopdrachten en dergelijke.

Het kwadrant linksboven bevat aanvullende diensten aan bestaande cliënten zoals bedrijven en andere organisaties en hun stakeholders. 
Daarbij kan worden gedacht aan performanceindicatoren (financieel en niet financieel) zoals informatie over klanttevredenheid, productkwaliteit, proceskwaliteit, doorlooptijd en dergelijke. Maar ook risicobeoordelingen (marktpositie, technologisch, financieel en personeel) en de kwaliteit van informatiesystemen, van internal controls en van de interne en externe rapportage behoren zeker tot de aandachtsgebieden.

Het kwadrant rechtsheneden biedt mogelijkheden om nieuwe cliënten audit-achtige services aan te bieden. Deze bieden met name mogelijkheden om kennis, methoden en vaardigheden die in de huidige audit-praktijk succesvol zijn gebleken als het ware te transplanteren naar andere omstandigheden en behoeften. Als voorbeelden worden gegeven de ISO 9000 certificatie en de auditing van informatie opgenomen in Internet.

Het kwadrant rechtsboven ten slotte w'ordt het meest riskant maar ook het meest uitdagend geacht. Het betreft informatie- en assurancebehoeften waarin thans noch door accountants, noch door andere dienstverleners wordt voorzien, maar waar het Special Committee een grote potentiële marktvraag voorziet.

Door actieve research, voorbereiding en ondernemerschap kan het accountantsberoep zeker een deel van deze dienstverlening in de toekomst gaan verzorgen. Of zoals de commissie het noemt: 'brand them as CPA services.'

Voorbelden zijn: assurance services in relatie tot elektronische transactiesystemen en dan met name gericht op de betrouwhaarheids-, beveiligings-en privacy-aspecten. Ook worden mogelijkheden onderzocht op nieuwe terreinen als geriatric assurance en health care effectiveness assurance.

Wat betekent dit alles nu voor de nabije toekomst van het accountantsheroep?

Wij moeten ons realiseren dat de in de matrix weergegeven veranderingen nog maar een beperkte afspiegeling zijn van de mutaties die zich in onze maatschappij voltrekken. Voortgaande technologische innovaties en de steeds voortschrijdende informatisering beïnloeden van jaar tot jaar het aanbod en de vraag van goederen en diensten. Voor bedrijven zijn reorganisaties, herstructurering, kostenreducties alsmede de noodzaak tot het opvoeren van productiviteit en kwaliteit aan de orde van de dag. Velen ervaren deze ontwikkelingen als chaotisch en een vermenigvuldiging van risico's voor bedrijf en maatschappij. Tot op zekere hoogte kan dit ook niet worden ontkend. Maar met dergelijke constateringen zijn managers, werknemers en alle andere belanghebbenden bij een bedrijf of instelling niet gebaat.

Accountants kunnen zeer veel bijdragen aan de eisen die aan de kwaliteit van informatie in een digitale wereld worden gesteld. Zowel wat betreft de interne als de externe informatievoorziening. Hetzelfde geldt voor de beheersing van risico's waarmee een onderneming wordt geconfronteerd. Risico's zowel op ondernemingsniveau als binnen afdelingen en processen. Managers verwachten ook dat de accountant vanuit zijn specifieke expertise ten aanzien van deze onderwerpen een maximale toegevoegde waarde levert.

Aan deze verwachtingen kan echter alleen worden voldaan als de weg van de jaarrekeningcontrole naar het bredere concept van de assurance services verder wordt ingeslagen.

Dat zal grote inspanningen vergen van kantoren en diensten en van de beroepsorganisatie, maar het meest van de individuele man of rouw in de dagelijkse praktijk.

De opleiding en training van jonge accountants, de nieuwe generatie, zal eveneens veranderingen moeten ondergaan De beroepsopleidingen zullen nog directer moeten aansluiten bij de wijze waarop bedrijven in deze tijd worden gemanaged en op de daarbij passende open communicatie tussen bedrijf en maatschappij.

\section{I T E R A T U U R}

Interim-Report Special Committee on Assurance Services,

(1996). American Institute of Certified Public Accountants, New York.

Interim-Report Special Task Force on Assurance Services, (1996), Canadian Institute of Chartered Accountants, Toronto.

Report of the Inter-Institute Vision Task Force, (1996), Canadian Institute of Chartered Accountants Toronto. Auditing into the Twenty-First Century, (1993), The Institute of Chartered Accountants of Scotland, Edinburgh. 